DOI https://doi.org/10.18551/rjoas.2018-04.24

\title{
THE RITUAL OF BAYAR SAUT AT TEWANG TAMPANG VILLAGE AT PAYAWAN SUB-DISTRICT, KATINGAN DISTRICT OF CENTRAL BORNEO
}

\author{
Rahmawati Ni Nyoman* \\ Hindu State College of Tampung Penyang, Palangka Raya, Indonesia \\ Ruastiti Ni Made \\ Indonesian Institute of the Arts Denpasar, Indonesia \\ *E-mail: ninyomanrahmawati0202@gmail.com \\ ORCID: 0000-0002-7048-179x
}

\begin{abstract}
This research aimed to know and understand the ritual of Bayar Saut at Tewang Tampang Village of Payawan Sub-District, Katingan District of Central Borneo. This research was conducted due to the uniqueness of religious life in the area. Practically, Muslims do not participate in the implementation of the ritual of Bayar Saut. However, the reality was different. Although the ritual of Bayar Saut is an animism tradition, but Muslims in Katingan District of Central Borneo participated in implementing the ritual. All data, which had been collected by the techniques of observation, interview, and literature studies, were analyzed using phenomenology and hermeneutic theories. The findings of the research showed that: the ritual of Bayar Saut (fulfilling promise) was implemented in the form of offering ceremony that offered food and sacrificial animal such as cow for sahur parapah/gaduhan (supernatural creature) which was believed to help them during the time looking for fortune, providing protection from danger and disease; currently, the local society was still implementing the ritual of Bayar Saut because it was based on the religious, social and cultural ideologies; the society of Tewang Tampang Village, Katingan District of Central Borneo still implemented the ritual of Bayar Saut due to positive implications on their social, economic, and cultural lives. Their belief was so strong against the myth of the essence of life underlying the ritual that Muslims in Tewang Tampang Village, Katingan District of Central Borneo still participated in implementing the tradition of the ritual up to now.
\end{abstract}

\section{KEY WORDS}

Ritual, Bayar Saut, religious life, local culture.

Indonesia is an archipelagic country that has various cultures in the form of traditions, customs, beliefs, and so forth. The cultural diversity is coloring the attitude of people in their daily lives. One of them appears in the dialectic of religion with the local wisdom which forms new variants as cultural characteristics in each region. Local wisdom, as a cultural wealth, is very influential on the attitude of society in religious life in Indonesia. One of them appears at the religious attitude of Muslims in Tewang Tampang Village, Payawan Sub-District, Katingan District of Central Borneo, which currently have always participated in the implementation of the ritual of bayar saut. In fact, the ritual is classified as an animist practice that is prohibited in the teachings of Islam.

The ritual of bayar saut is a ceremony to fulfill the promise to sahur parapah/gaduhan (supernatural creature) which are believed to help the people of Dayak Kaharingan in looking for fortune and protecting them from danger and disease. The ritual of bayar saut is led by a pisor (ceremonial leader) who has been sanctified by the people of Dayak Kaharingan. They fulfill the saut with the offerings in the form of food and sacrificial animal such as cow or chicken according to the promised that has been made. The ritual is usually implemented in the house of person who is fulfilling the saut. After implementing the ceremony, the offerings dilarung (are thrown) to the river crossing the Tewang Tampang Village of Payawan SubDistrict. 
The research setting was located in Central Borneo, precisely in Tewang Tampang Village, Payawan Sub-District of Katingan District. Geographically, Tewang Tampang Village is bordered with Petak Bahandang Village in the east, it is bordered with Luwuk Kiri Village in the west, it is bordered with Luwuk Kanan Village in the north and it is bordered with Tumbang Panggo Village in the south. Tewang Tampang Village is crossed by a large river called the Katingan River which also separates Tewang Tampang Village with Luwuk Kiri Village and Tumbang Panggo Village.

Tewang Tampang Village can be reached through two transportation routes; that are through the river and land. In the past, water taxi was the main transportation used by the society to connect between one village and another. Currently, by the development of the era, that mean of transportation has now begun to be abandoned. However, if the rainy season and floods come, then this water taxi becomes popular again. Even so, water taxi is the only mean of transportation that can be used by the society.

Currently, the society of Tewang Tampang Village prefers to use land transportation by using a motorcycle or four-wheeled vehicles. There are two land routes that can be used to reach Tewang Tampang Village; through Hampangen Village and Luwuk Kiri Village. Passing through Hampangen Village needs caution to go because it is still a ground road and full of deep holes. When the rainy season comes, the area is flooded by water and is hard to pass. Meanwhile, other road that can be passed to go to Tewang Tempang Village is through Kasongan city but this path is not directly connected to Tewang Tempang Village because it is separated by the river. Therefore, from Luwuk Kiri Village, people have to ride getek (ferry boat) that can be rented from the local society. Then, people can use the land route again.

The road facilities of Tewang Tampang Village are very good. It is a concrete road with a width of \pm 3 meter making it easier for the people to do their daily activities. In addition to be used for daily activities such as bathing, washing, and others, the Katingan River crossing Tewang Tampang Village is used for the economic field as a place to fish on the edge of the river, to raise fishpond and to mine the gold.

Initially, the natives of Central Borneo were the society of Tewang Tempang; the Dayak Katingan. According to the elders of the village, approximately 200 years before the century, there was the first migration of Malay nation to Indonesia from Yunan area. They come in waves inhabiting the beach. Broadly speaking, Dayak tribe in Borneo is divided into seven major tribes and then each is divided into smaller sub-tribes, among them are Dayak Ngaju, Dayak Apukayan, Dayak Iban, Dayak Murut, Dayak Punan, Dayak Ot Danom, Dayak Park, Dayak Katingan and Malay tribe.

The tribe of Dayak Katingan which is also often called as Dayak Kaharingan adheres to the beliefs of Hinduism. According to the Dayak Kaharingan belief, their tribe coma from the seventh heaven (according to tetek tatum). Some others say that they came from Proto Melayu. The tribe of Dayak Kaharingan believes that their tribe was descended from the seventh heaven by using Palangka Bulau by Ranying Hatalla. It was mentioned that the ancestor of the Dayak Kaharingan tribe was descended by using Palangka Bulau in Tantan Puruk Pamatuan (the upstream of Kahayan and Barito Rivers), Tantan Liang Mangen Puruk Kaminting (around Gunung Raya), Datah Tangkasiang (the upstream of Malahui River) in West Borneo, and Puruk Kambang Tanah Siang (the upstream of Barito River) (Riwut 2003).

Since the colonial period in Indonesia, many people of Dayak Kaharingan adhere to Islam and Protestant Christianity. Nowadays, the people of Tewang Tampang Village, Katingan District of Central Borneo live in religious plurality. There are three religions adhered by the society of Tewang Tampang Village of Katingan District namely Hindu Kaharingan, Islam, and Protestant Christianity. Each of these religions has the same percentage of adherents and they live together. There are many of them even have close fraternal blood ties. Therefore, many families in Tewang Tampang Village live in one house in harmony with religious plurality.

In the midst of that harmonious religious life, there are various unique and interesting phenomena to be studied. One of them is the ritual of bayar saut implemented by Muslims. The ritual of bayar saut is an offering ceremony in the form of food and animal sacrifice such 
as cow for saur sarapah/gaduhan (supernatural creature) in which the local society believe that they have helped them in looking for fortune and giving them protection from danger and all kinds of diseases.

As Muslims, their religious life is actually based on the teachings of the Holy Qur'an and Hadith too. In their dogma, they recognize the existence of a single reality (monotheism) as the ruler of the universe; it is Allah and Mohammed as the messenger of Allah. The reality of God as understanding of monotheism is reflected in the two sentences of the shahada: "ašhadu'al lā 'ilāha 'illā-llāh" means: I testify that there is no god but Allah, written in the Quran Surah (37) Ash-Shaffat verse 35 and also in the phrase "wa'ašhadu 'anna muhammadur-rasūlu-Ilāh" means: I testify that Muhammad is the messenger of Allah, written in Surah (48) Al-Fath verse 29.

All rituals in Islamic beliefs are carried out in accordance with the provisions which Allah has said through the Qur'an and hadith. The ritual in Islamic belief is carried out by Salah. According to Djamali (1992), Salah is a series of sayings and actions beginning with the recitation of takbir (takbiratul ihram, Akbar Akbar) and ending with salaam (assalammu'alaykum) in a particular process of reading and movement. Based on its natures, there are two rituals in Islam consisting of routine rituals that are carried out periodically and incidental rituals that are carried out at certain times.

This research was conducted due to the imbalance between the expectation and the reality. Those who embrace Islam should have not performed animist rituals. However, the reality was different. Although people in Tewang Tampang Village, Katingan District of Central Borneo adhered to Islam but in reality they still implement the ritual of bayar saur in which they believe in the existence of spirits or supernatural powers. The questions are: how is the form of the ritual of bayar saut?; why do they implement the ritual ?; what are the implications for their lives in this global era?

\section{METHODS OF RESEARCH}

This research applied qualitative method. The data source of this research is the implementation of the ritual of bayar saut, the relevant informants such as the elders, the leaders, and the society og Tewang Tampang Village, Katingan District of Central Borneo. In addition to the primary data sources, this research also used secondary data sources which were obtained from the previous research findings. All data, which had been collected by the techniques of observation, interview, FGD, and literature study, were analyzed critically using phenomenology and semiotic theories.

\section{RESULTS OF DISCUSSION}

The Implementation Form of the Ritual of Bayar Saut. The Islamic society of Dayak Katingan in Tewang Tampang Village of Central Borneo implemented the ritual of bayar saut (fulfilling promise) as the offering ceremony in the form of offerings containing food and sacrificed animal such as cow. The offerings were presented to the parapah/gaduhan (supernatural creature) that was believed to help their lives so far, especially in seeking fortune and providing protection from danger and all kinds of diseases.

Silo (the Pisor who usually led the ceremony of bayar saut) mentioned that not everyone has the good fortune to keep sahur parapah/gaduhan, as the lucky one will be visited by the supernatural spirit by dream. Moreover, in the matter of inheritance, the supernatural spirit chose itself who to follow. Those who keep the supernatural spirit known as sahur parapah/gaduhan believe that in addition to direct protection they will also be able to ask for special help based on what is desired. For example, when they are going to have long-journey travelling, they want to be taken care and protected from danger. Moreover, they want to be assisted in looking fortune, to be guarded from the intrusion of bad guys or evil beings, and much more. 


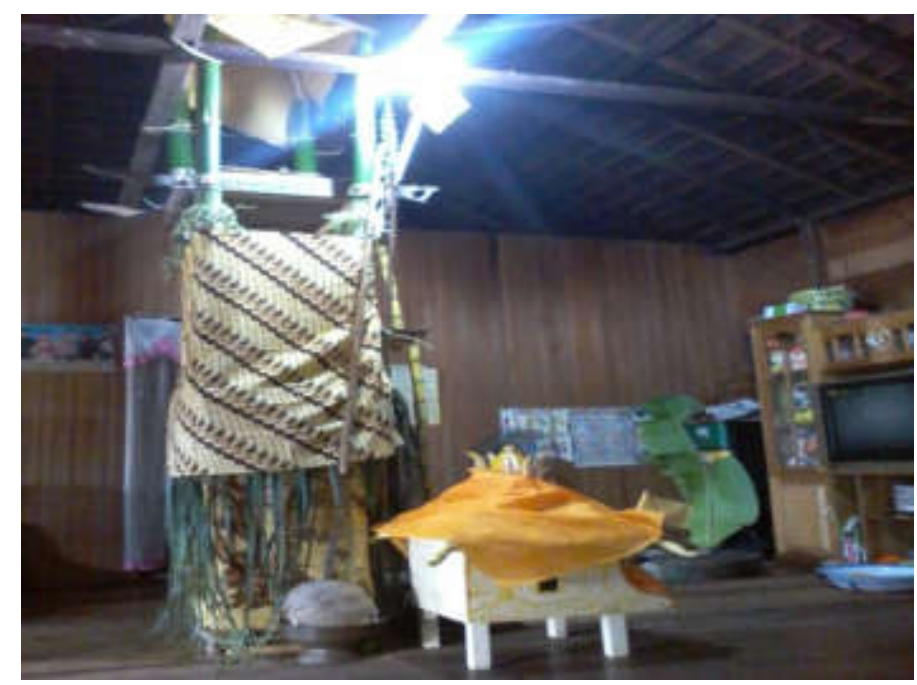

Figure 1 - Palangka as the place for worshiping sahur parapah/gaduhan (supernatural spirit) which is built inside the house (Documentation: Rahmawati, 2017)

In that palangka building, the society of Dayak Katingan offered the offerings before the offerings were brought to the river. According to Silo, if the family keeping the supernatural spirit wants to ask for help then they must call the creature by using the means of beras tawur, it is a kind of rice that has been given some powers through the spell. The beras tawur is then spread out with the spell whose contents are about the purpose and the purpose of arrival while promising to give offerings as a form of gratitude to the supernatural spirit. If their request has been granted then the person must offer to the supernatural spirit the offerings based what has been promised. If the promise is not kept it is believed that the supernatural spirit will be angry or mad and disturb the family. The tradition of fulfilling the promise in the society of Dayak Kaharingan at Tewang Tampang Village of Central Borneo is called the ceremony of "bayar saut". The following is a palangka building which is built inside a house where the supernatural spirit so-called sahur parapah/gaduhan is worshipped.

The implementation of the ritual of bayar saut is based on the holy book of Panaturan. According to Kencong (2006), every ritual performed by the society of Dayak Kaharingan at Tewang Tampang Village, Katingan District of Central Borneo is always based on the teaching concept of Bawi Ayah, Raja Uju Hakanduang and Kanaruha Hanya Basakati who are commanded by Ranying Hatalla Langit to go down again to the earth and teach the descendants of King Bunu on the teachings of marriage, society, and the teachings relating to ceremonies and upakara from the lowest to the highest levels. Based on Panaturan section 41 verse 2 , which reads:

"Amun kalute ampin kakare taluh handiai, huang pambelum anak esun Raja Bunu mijen Pantai Danum Kalunen, ije jadi uras nalingau kakare ajar RANYING HATALLA, te RANYING HATALLA hamauh ayak nyahuan Raja Uju Hakanduang, Kanaruhan Hanya Basakati, uka hadurut nanturung Lewu Telu Kalabuan Tinggang, Rundung Epat Kalehulun Talawang"

It means:

"Considering the life situation of the grandchildren of Raja Bunu who live on Danum Kalunen Beach, who have forgotten much about the teachings of RANYING HATALLA, therefore RANYING HATALLA said and ordered Raja Uju Hakanduang Kanaruhan Hanya Basakati to get down to Lewu Telu Kalabuan Tinggang, Rundung Epat Kalehulun Talawang"

Section 41 verse 2 of the holy book of Panaturan as mentioned above is giving instructions to Raja Uju Hakanduang and Kanaruhan Hanya Basakati, to immediately get down to Danum Kalunen (the universe) to re-teach the human race (the descendants of Raja Bunu) various small and large rituals as paths to get closer to the Ranying Hatalla Langit and all its manifestations, and at the same time as a means of asking for help if necessary. 
One form of ritual which is also believed to be the teaching of the Ranying Hatalla Langit through Raja Uju Hakanduang and Kanaruhan Hanya Basakati is the ritual ceremony of bayar saut. In practice, the ritual of bayar saut is adjusted to the amount of the promises that have been mentioned to the supernatural spirit. If the promise is about to sacrifice a pig or a cow then it would be a big ritual, but if the promise is about to sacrifice only a chicken then it would be a small ritual. In practice, according to the ceremonial leader called Silo (ceremonial leader), a big ritual must establish a small building as a place of offerings socalled palangka and sapundu buildings to place the sacrificial animals, as shown in Figure 2.

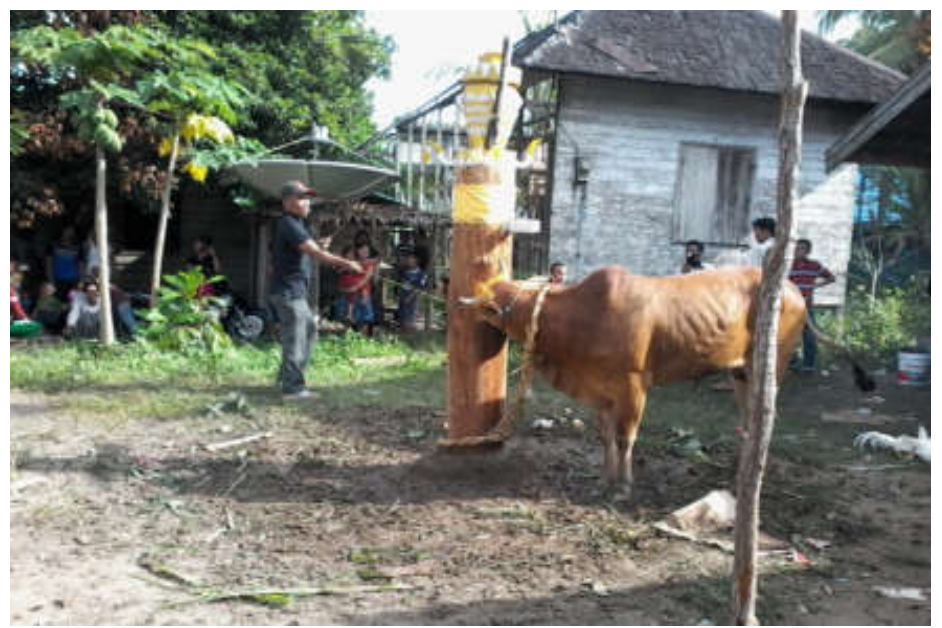

Figure 2 - Sapundu building, a place of offerings and sacrificial animals to be offered to the supernatural spirits in a big ritual of bayar saut (Documentation: Rahmawati, 2017)

If it is a small ceremony then the offerings are meals equipped with sacrificial animals in the form of chicken as shown in Figure 3.

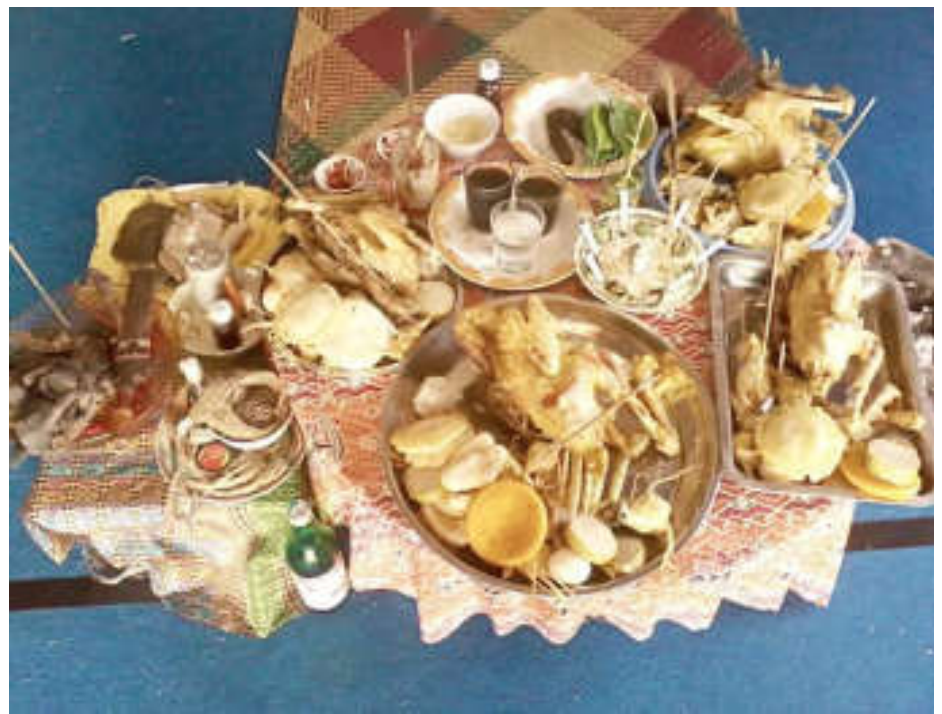

Figure 3 - The offerings are in the form of meals with chicken in a small ritual of bayar saut (Documentation: Rahmawati, 2017)

The above offerings are dedicated to the supernatural spirit using nyiru or trays in the palangka buiding which is built inside the house.

The ritual of bayar saut is usually led by a Pisor/Basir (a ceremonial leader who has been consecrated). The procedures for the implementation of the ritual of bayar saut begin with menawur or spread out the rice that has raised its power through spells and prayers so it 
is believed to be an intermediary to convey or invite the supernatural spirit (sahur parapah) to come in the ritual ceremony of bayar saut which is being implemented.

The next stage is to implement hasaki palas; it is the ceremony of purification of ceremonial means and facilities by using tamping tawar (white rice flour) and parapen to honor the angels who come along with sahur parapah in that ritual of bayar saut. After implementing the ceremony of purification of ceremonial means and facilities, hasaki palas ceremony was conducted by using tamping tawar (white rice flour) and parapen as the welcoming ceremony. All family members dance (mengajan). They dance around the ceremonial facilities and facilities that will be offered to the supernatural creature.

By using a long scarf or cloth for female participants strapped around their necks, they dance around the offerings, as shown in the following figure.

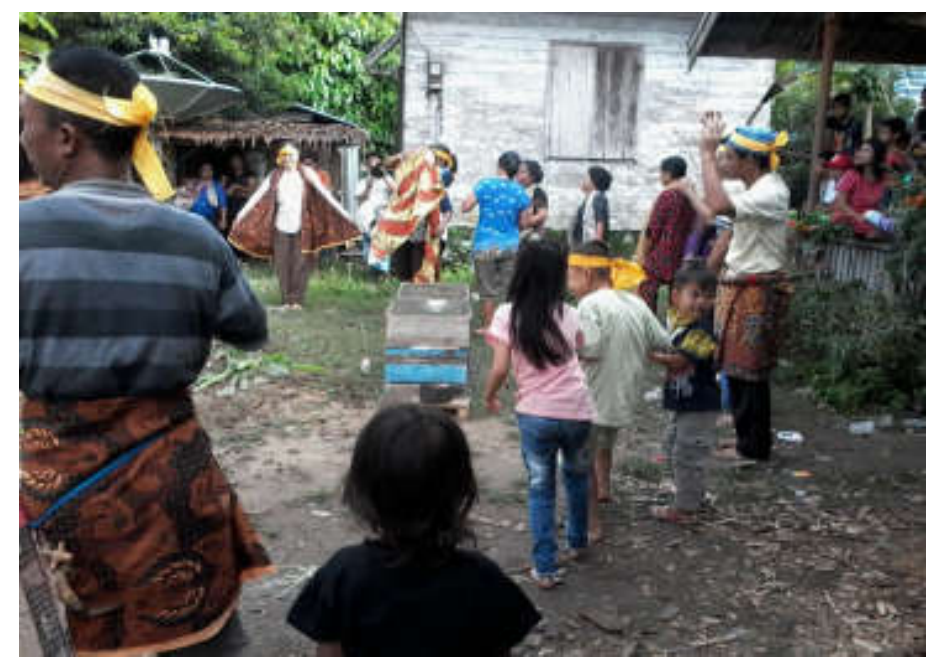

Figure 4 - The families dance (mengajan) using a scarf that is worn around the neck and they go around the means and the facilities of a big ceremony of bayar saut)

(Documentation: Rahmawati, 2017)

After implementing the welcoming ceremony for the supernatural spirit, then it comes to turn at the peak of the ritual of bayar saut. The members of the family alternately offer the offerings equipped with sacrificial animal such as the cow. It is carried out by spearing the sacrificial animal (cow) to bleed and die then the blood of the sacrificial animal attached to the spear is then smeared onto each of the foreheads of the family members who participate in implementing the ritual of bayar saut as a sign that the promise to the supernatural spirit has been completely fulfilled. The person who has made the promise even considered to be free from debt or has cleaned himself/herself (hasaki palas) from the debt promise to avoid the undesirable things.

In addition, the blood of the sacrificial animals that falls on the ground is interpreted as the purge of the earth or the foot ground by the local society. In the future, it is no need to worry when having a small child who has not tossed his/her feet to the ground because the ground has been considered as pure and clean.

After the sacrificial animal (cow) died then the flesh is bred and cut into pieces. Some of the beefs are offered for offerings and the others are distributed to the people who live nearby. The beef to be offered is placed inside the palangka building (a place for worshipping the supernatural creature) to be brought to the residence of the person implementing the ritual bayar saut or to be brought to the river according to the clue of the paranormal or the person leading the ritual of bayar saut.

The Ideology Underlying the Implementation of the Ritual of Bayar Saut. The society of Dayak who adheres Islam in Tewang Tampang Village, Katingan District of Central Borneo is still implementing the ritual of bayar saut due to positive implications on their social, economic and cultural life in that place. Their belief in the mythology about the essence of life 
that underlies the ritual is so strong which has made them keep the ritual of bayar saut up to now.

The people of Dayak Kaharingan in Katingan District of Central Borneo are able to live harmoniously between religious life of Hindus, Muslims and Protestant Christians in one big family. Although they embrace different beliefs in a family, they can still maintain a harmonious family, especially in implementing the ritual of bayar saut.

The totality of the ritual of bayar saut implemented by Muslims in Tewang Tampang Village of Katingan District is based on the belief that there are supernatural powers around them. Ideologically, the integrative movement of the Muslims of Dayak Kaharingan in the implementation of the ritual of bayar saut is centered on sahur parapah or gaduhan as the regulator of supernatural powers. Sahur parapah is believed by the society of Dayak Kaharingan as a manifestation of Ranying Hatalla Langit (God) who is in charge of safeguarding and helping human life in the earth.

The power of sahur parapah in dealing with any supernatural annoyances for the life survival of the society of Tewang Tampang Village, Katingan District of Central Borneo is the main cause in which the local society across generations continues to implement the ritual of bayar saut. The sustainability is influenced by the ideology of cultural preservation that has become the basis of solidarity in a family. As a point of view in living the life, ideology can strengthen social relationships and maintain the stability of their lives together in groups (Sumantri and Zaimar, 2001). The strength of the relationship between the personals in a family results in the impact on the extent of their belief in sahur parapah. Therefore, there are not a few of members of the family who are Muslims also participate in implementing the ritual of bayar saut traditionally. In addition, for the sake of preserving their family culture and safety, they seem to ignore the prohibition of Islamic teachings.

Traditionally, the kinship in Tewang Tampang Village, Katingan District of Central Borneo gives freedom to the next generation to choose a religion under consideration that they keep and continue the tradition of their big family from their father or mother as long as their parents do not have their own house. After their parents are independent and have their own house, the child is welcome to live his/her parents under consideration that he/she understands the concept of huma betang to be able to respect the differences in the family, especially in cooperatively helping each other in preserving the tradition of the ritual of bayar saut.

Traditionally, in the implementation of the ritual of bayar saut, there is a kind of equation between a family member to a certain animal because it is considered to bring family's disgrace. The family's disgrace can be due to being married to own sibling (endogamy) and being married not in accordance with the customary provisions of Tewang Tampang Village, Katingan District of Central Borneo. To remove the labeling, they are required to participate in the ritual of bayar saut. Within the ritual, they must be willing to be called animal and walk by imitating the walking style until they arrive at dulang bawi. Upon the arrival, they are just considered to be purified (dipalas) and be removed their labeling by a basir, the leader of the ritual of bayar saut. However, when there are still objections from family members about the elimination of animal labeling, the customary party is ready to clarify and resolve the issue if the member of the family is willing to give the jipen to the customary board; it is such willingness to always participate in the ritual of bayar saut and make material compensation to the customary party, not to mention those who are Muslims. Ideologically, the aspects of cultural preservation from the actions of Muslims in Tewang Tampang Village, Katingan District of Central Borneo through the ritual of bayar saut at least have contribution to the resilience of the Dayak Kaharingan society in the midst of the social dynamics that occur in that place.

Dhavamony (1995) and Bakhtiar (2007) mentioned that every difference accompanied by the symptoms of weirdness is always caused by the supernatural powers of the spirits as the form of animism. In line with the statement, the religious life of Muslims in the Dayak Kaharingan family in Tewang Tampang Village, Katingan District of Central Borno is still convinced the existence of sahur parapah as a supernatural creature who is a guardian of their own, the family and the village. Therefore, they implement the ritual of bayar saut to 
revitalize the function of sahur parapah as a guardian of their own, the family and Tewang Tampang Village, Katingan District of Central Borneo and the identity of the descendants of Raja Bunu.

King Bunu is a figure that strengthens the resolve of Muslims in Tewang Tampang Village, Katingan District of Central Borneo to participate in the preservation of the cultural tradition of Dayak Kaharingan. They implement the ritual of bayar saut because they feel that they are the descendants of Raja Bunu. In the legend of Dayak Kaharingan tribe, Raja Bunu was mentioned as a messenger of Ranying Hatalla Langit as a danum kalunen for human life in the world. Therefore, the family of Raja Bunu received great attention and protection from the family of Raja Sangeng and Raja Sangiang until the entire family of Raja Bunu could be reunited with Ranying Hatalla Langit.

The descendants of the family of Raja Sangeng and the family of Raja Sagiang are known to be very respectful to the cultural heritage, be obedient in performing the rituals and have many members who master supernatural powers. Therefore, the family of Raja Bunu feels lucky especially related to the problems of life resulting from the disturbance of supernatural creature. Through the preservation practice of the ritual of bayar saut among Muslims in Tewang Tampang Village, Katingan District of Central Borneo, ideologically, it has labeled the respective status in religious life for the society of Central Borneo, not only because of the faith but by the royal genealogical relationship.

Takwin (2003) mentioned that ideology represents the main idea that is used as a guide for social groups in achieving their goals. The combination of local cultural preservation ideology and Islamic teachings has made the ceremony of bayar saut to be phenomenal in order to maintain the integrity of the family among religious diversity in Tewang Tampang Village. The Muslims in Tewang Tampang Village of Central Borneo are not only orienting to God worshipping, but also practicing the animism ritual of bayar saut as a religious ceremony.

Ideologically, the religiosity of Islam is a religion based on the movement of social groups to the Qur'an and Hadith. The two guidelines affirm only recognizing the supreme ruler of the universe that is Allah and Muhammad as the messenger of Allah. Muti'ah (2009) mentionoed that Islamic teachings are centralized in the concept of monotheism (tauhid) in which Allah is mentioned as the center of everything and they are required to dedicate himself only to Allah and are forbidden to associate Allah with others. The doctrine asserts that Muslim life should be oriented to devote only to Allah as the center of the destiny of life of all the monotheistic emphasis in Islam teachings. This matter seems paradoxical even contradictory in the implementation of Muslim worshipping in Tewang Tampang Village which is quite dependent on sahur parapah or gaduhan as the center of religiosity and the determinant of the destiny of life. It is carried out because of fear of a disaster that could happen to their family. Therefore, the society of Dayak Kaharingan implements and preserves the ritual of bayar saut. The fear is based on a belief to the stories of Dayak Kaharingan elders. As stated by Ernawati (41) and Yapin (45) about the stories of Dayak Kaharingan elders:

"Once in our village, there was a Haji who also had sahur parapah/gaduhan. He was a rich man and the number-one richest man in this Payawan District. But when he passed away, there was no son who would continue the ritual. Finally, one-by-one of his child was sick, got accidents and some even died. The wealth is now end and their lives are now very worrisome."

The above explanation by Ernawati (41) and Yapin (45 years) is one of the stories in the society of Tewang Tampang Village which is believed to be authentic, so they are afraid to abandon the tradition of the ritual of bayar saut. The statement of Ernawati (41) and Yapin (45) were reinforced by the statement of Bapa Teguh as a Muslim who still maintains the ritual of bayar saut as a family tradition. The ritual of bayar saut is a necessity and a must to be preserved. The conviction was affirmed by Bapa Teguh who said that:

"...choosing to continue the tradition of the ritual of bayar saut after knowing that his child and wife almost died because they were disturbed by sahur parapah or gaduhan who had been worshiped by his previous datuk. The reasons justifying the decision to re- 
implement the ritual are (1) sahur parapah or gaduhan is considered not as a genie or a demon, but a supernatural creature that can become friend and help family life, (2) inside the tradition of Islamic teachings, it teaches about the Mikail angel who is assigned by Allah to bring down rain and share fortune. The role of sahur parapah or gaduhan in the tradition of Dayak Kaharingan family is considered very identical with the Mikail Angel which is honored through the implementation of the ritual of bayar saut".

Based on the statement of Bapa Teguh, it showed that the Muslims of Dayak Kaharingan try to apply the Islamic teachings that can synergize with the customs of the Dayak Kaharingan family, so that they can live harmoniously in religious differences in a family as the main reference. The reference of social action is firmly rooted in the superstructure of its people. That superstructure level includes ideology (Sanderson, 1993; Suardika et al., 2006; Kerepun, 2007; Supriyono, 2005; Atmadja, 2006). It means that in relation to the implementation of the ritual of bayar saut, it is ideally established and is based on the construction of knowledge that accommodate the desire of the majority of social groups in fostering the kinship structure. In other words, ideologically, the necessity for the implementation of the ritual of bayar saut among Dayak Kaharingan Muslims as a family tradition is more based on the importance of cultural preservation than the quest for heaven in Islamic religion. Moreover, Elsutha (2013: 45) mentioned the fact that the Qur'an and Hadith as a religious guideline have no verses that require the people to perform the ritual of bayar saut. It is also written in An-Nisaa verse 48 which states that:

"Indeed, Allah does not forgive association with Him, but He forgives what is less than that for whom He wills. And he who associates others with Allah has certainly fabricated a tremendous sin." (Surah An-Nisa: 48)

According to Surah An-Nisa: 48, Islam does not religiously justify the ritual practice which is offered other than Allah. The practice is hereditary and it is more based on family heritage and customary interests for the harmonization of life of Dayak Kaharingan tribe in Tewang Tampang Village of Central Borneo.

The ritual bayar saut is a form of cultural negotiation of Dayak Kaharingan in Central Borneo that use cows as a substitute for pigs by Muslims. It is contrary to the statement proposed by Medi, Religious School Students on May 20, 2017:

"...actually there are no rituals and tawur that use cows, it is only chickens and pigs".

Based on Medi's statement, it can be seen that there are negotiations through the rituals that use sacrificial animal. The practice of the ritual becomes increasingly sacred because it involves the form of religious symbols such as clothing. As one form of religious activity, the obligatory clothing for Muslims during the implementation of ritual of bayar saut is traditional clothes of Dayak Kaharingan tribe. That matter ideologically affirms the preservation of Dayak Kaharingan culture to be the central force that encourages the movement of Muslims in Central Borneo to continuously perform the ritual of bayar saut.

The Implication of the Implementation of the Ritual of Bayar Saut. Currently, the society of Tewang Tampang Village, Katingan District of Central Borneo continues to implement the ritual of bayar saut for positive implications on the social, economic, and cultural life of the local society. Their belief in the myth of the essence of life that underlies the ritual is so strong that until now the Muslims in Tewang Tampang Village, Katingan District of Central Borneo still implements the tradition of the ritual.

Ideological dialectics of Islam in the ritual of bayar saut as a tradition of the society of Dayak Kaharingan in Tewang Tampang Village, Pintawan Sub-District Katingan District of Central Borneo indirectly have implications for social life for Muslim in religious life especially Muslims in Tewang Tampang Village, Katingan District of Central Borneo. It is characterized by the strengthening of kinship relationship of Dayak Kaharingan people. The basis of the solidarity also refers to the personal matter. Barker (2000: 218$)$ asserts that the identity of a collection of tastes, beliefs, attitudes and lifestyles can be both a gap and a reinforcement of a colony of a social group.

Identity is an element of the formation of social reality. In addition, it is an identity that crystallizes and is preserved, modified and even transformed through various forms of social relationships. In that context, the identity of Muslims in the society of Dayak Kaharingan is 
seen as part of social facts as well as a source of guidance in religious activities including in performing the ritual of bayar saut.

The implementation of the ritual of bayar saut has implications for strengthening of customary identity to the society of Dayak Kaharingan tribe in Tewang Tampang Village, Katingan District of Central Borneo. Eriksen in Maunati (2004: 29) mentioned that identity as a social construct can strengthen the recognition of members of their social groups among other social groups. The identity of the Dayak Kaharingan tribe can be characterized by cultural material factors such as food, clothing, housing, equipment and non-material factors such as language, customs, belief systems, knowledge and attitudes that can give the exclusivity of social standing.

The attitude of exclusivity is socially-politically known as strict, rigid and less able to relate and cooperate with other groups. They are easy to blame and disbelieve others for not agreeing with the group. However, it is different with the attitude of Muslims who participate in the implementation of the ritual tradition of bayar saut which has a more open and flexible kinship structure about the aspects of religious differences in the society relations without having to change and adapt the exclusivity aspect of each of the religious followers in Tewang Tampang Village, Katingan District of Central Borneo. In addition, its involvement has succeeded in removing the indoctrination of the infidels among the groups of Muslims who implement the ritual of bayar saut in that village. In addition, it is about the openness of the religious dialogue, not only in a family but among families in Tewang Tampang Village, Katingan District of Central Borneo on the issue of sensitive piety and taboo of every religion.

Latane in Rahardjo (2005: 250) argued that actually a dialog between individuals can be formed when the individuals are not in isolated situations. The religious life in Tewang Tampang Village, Katingan District of Central Borneo interacts in a social space, an area where they can meet, communicate and try to influence each other. In other words, the gap aspect of each religious identity of the ritual actors is significantly decreasing.

Knitter in Kusuma Dewi (2013: 26) argued that religious identity should be a representation of one's faith consciousness, apart from a priority piety due to the cultural and social situation. Religious identity in the structure of the implementation of the ritual of bayar saut is still used, synergized as a complement and reinforcement of faith which is more influenced by the genealogy of the Dayak Kaharingan cultural tradition. The sustainability of the situation has already implicated the formation of a priority piety that is socially the basis for the denial and the eradication of the pathology of social groups.

The disgrace of the family is still a problem that is fought in the life of diversity through the establishment of a priority piety to the preservation of the ritual of bayar saut in Tewang Tampang Village, Katingan District of Central Borneo. Thus, the establishment of a priority piety to the preservation of the ritual of bayar saut already has implications for the affirmation of social respect to the society in Tewang Tampang Village, Katingan District of Central Borneo, not least for Muslims.

The ritual of bayar saut has already had economic implications on the religious life especially the Muslims in Tewang Tampang Village, Kantingan District of Central Borneo. In addition to the aspect of religiosity which is focused on sahur parapah, Muslims in Dayak Kaharingan society believe that it can arouse the Mikail angel who is assigned by Allah to bring down rain, arrange sustenance, and able to grant financial improvement and ease of sustenance.

Muslims in Dayak Kaharingan society, who get the ease of sustenance and financial improvement after performing the ritual of bayar saut and who believe in the source of the blessing, tend to enlarge the sacrificial aspect and the form of ritual celebration in the next period as a form of gratitude and socio-economic prestige in Tewang Tampang Village, Kantingan District of Central Borneo. The large number of Muslims who were granted their wishes in obtaining the ease of sustenance and financial improvement resulted in ritual contestation on a considerable scale as evidence that the economic condition of a family in Dayak Kaharingan society in Tewang Tampang Village, Kantingan District of Central Borneo is better than before. Socio-economically, the form of the contestation of the ritual of bayar saut in Tewang Tampang Village, Kantingan District of Central Borneo can result in 
increasing the flow of economic turnover for the ritual purposes as well as showing to the public that the establishment base of the Dayak Kaharingan society has become more evenly and increased. Thus, it can be concluded that the involvement of Muslims in the ritual of bayar saut already have economic implications for the affirmation of the structure establishment of Dayak Kaharingan society in Tewang Tampang Village, Kantingan District of Central Borneo.

The ritual of bayar saut already has cultural implications on religious life in Tewang Tampang Village, Kantingan District of Central Borneo. The cultural implications of the ritual implementation in Tewang Tampang Village, Kantingan District of Central Borneo have given a distinctive style to the dignified Islamic life in that village. Maryadi (2015: 25) mentioned that maintaining social religiosity relates to the contribution of religion held by the society, where the practice of religion can synergize with the cultural heritage of the society.

Basically, a culture of a society is a manifestation of the combined mindset, behavior and social value system. In that context, the religious practice of a family in Tewang Tampang Village of Central Borneo is seen as part of the struggle of existentiality through the integrity and integration of diverse religions with the culture of Dayak Kaharingan.

The sustainability of the ritual implementation of bayar saut can contribute significantly to the preservation of the identity of Dayak Kaharingan cultural traditions in Central Borneo. Ritherfoed in Piliang (2006: 279) mentioned that identity is a link that connects cultural values and social needs. In the religious life of the Dayak Kaharingan family, there are many people of Tewang Tempang Village mentioned that the ritual of bayar saut is part of Hindu Kaharingan teachings. Meanwhile, among Muslim and Christian group, they clarified that the implementation of the ritual of bayar saut is only limited to customary activities of Dayak Kaharingan tribe. In other words, Hindu groups of Dayak Kaharingan society is considered need more perfection of their faith.

The aspect of benefits gained especially for the Muslims from the implementation of the ritual of bayar saut is the improvement of sensitivity and concern for the aspect of cultural settlement of Dayak Kaharingan in Central Borneo optimally and plural aspect of religious culture among the flow of social change in Tewang Tampang Village of Central Borneo. Thus, the cultural implications of the implementation of the ritual of bayar saut have contributed to the form of community welfare in Tewang Tampang Village of Central Borneo.

\section{CONCLUSION}

Based on the discussion, it can be concluded that the society of Tewang Tampang Village of Central Borneo implemented the ritual of bayar saut (fulfilling promise) in the form of offering ceremony using the offerings in the form of sacrificial food and animal. The offerings are dedicated to supernatural creature so-called parapah/gaduhan that is considered to help them in seeking fortune and protect their lives from various dangers and disease. The local society believes that sahur parapah/gaduhan is a manifestation of Ranying Hatalla Langit or God in the form of supernatural creature that has the duty of helping the lives of mankind. The ritual of bayar saut that is interpreted as a ritual ceremony to fulfill the promise to sahur parapah/gaduhan (supernatural creature) is implemented by the stages: (a) inviting Gods, angels, and sahur parapah to attend the ceremony, (b) purifying ceremonial means (hasaki palas), (c) dancing together, (d) offering the sacrificial animal with spears, and (e) delivering offerings to the river after the offering ceremony is completed.

The ritual implementation of bayar saut by Muslims in Tewang Tampang Village of Central Borneo did not result in conflict as some components of the ritual ceremony of bayar saut were replaced; as replacing pigs with cows as the sacrificial animals and replacing the use of prayer rugs and veils for Muslim women by using traditional clothing of Dayak Kaharingan

The Islamic society in Tewang Tampang Village of Central Borneo is currently implementing the ritual of bayar saut for positive implications on the social, economic and cultural life of the local society. The ritual of bayar saut continues to be implemented by Muslims in Tewang Tampang Village, Kaharingan District of Central Borneo because it 
showed the pluralism point of view in religious life. The ritual of bayar saut is enrichment forms of Muslim life in Indonesia. Their belief was so strong against the myth of the essence of life underlying the ritual that Muslims in Tewang Tampang Village, Katingan District of Central Borneo still participated in implementing the tradition of the ritual up to now.

\section{REFERENCES}

1. Agus Bustanuddin. 2005. Agama Dalam Kehidupan Manusia Pengantar Antropologi Agama. Jakarta.

2. Atmadja, Nengah Bawa. 2006. Seabad Puputan Badung: Perspektif Belanda dan Bali. Denpasar: Pustaka Larasan.

3. Bakhtiar, Amsal. 2007. Filsafat Agama: Wisata Pemikiran dan Kepercayaan Manusia. Jakarta: Raja Grafindo.

4. Barker, Chris. 2000. Cultural Studies. Yogyakarta: Kreasi Wacana.

5. Dhavamony, Mariasusai. 1995. Fenomenologi Agama. Yogyakarta: Kanisius.

6. Djamal, Hendropuspito. 1992. Sosiologi Agama. Yogyakarta: Kanisius.

7. Djamli.Abdul.R. 2002. Hukum Islam Berdasarkan Ketentuan Kurikulum Konsorsium IImu Hukum. Mandar Maju. Bandung.

8. El-sutha, Saiful Hadi. 2013. Panduan Sholat Lengkap. Jakarta: Wahyu Media.

9. Geertz, 1989. Abangan, Santri, Priyayi dalam Masyarakat Jawa, terjemahan, Jakarta.

10. Jamaludin. 2015. Agama \& Konflik Sosial Studi Kerukunan Umat Beragama, Radikalisme, dan Konflik Antar Umat Beragam. Bandung. Pustaka Setia.

11. Kencong, 2006. Upakara Hindu Kaharingan (Suatu Tinjauan bentuk, fungsi, dan makna dalam Agama Hindu) Tesis, IImu Agama dan Kebudayaan UNHI, Denpasar.

12. Kerepun, 2007. Mengurai Benang Kusut Kasta. Denpasar: Empat Warna Komunikasi.

13. Koentjaraningrat, 1994. KebudayoanJawa, Jakarta: Balai Pustaka.

14. Kusuma Dewi, Subhani. 2013. "Peaceful Comptition Dalam Keluarga Beda Agama: Sebuah Ancaman atau Potensi?". Jurnal Religi Vol. IX, No.1, Januari 2013: 23-37.

15. Maryadi Sisva \& Dhanik P. Septi. 2015. Menjaga Mitos Kearifan Tradisional Masyarakat Dayak Halonh Dalam Pelestarian Lingkungan di Kalimantan Selatan. Yogyakarta.

16. Maunati, 2004. Identitas Dayak: Komodifikasi dan Politik Kebudayaan. Yogyakarta: LKiS.

17. Muti'ah. 2009. Harmonisasi Agama dan Budaya di Indonesia. Jakarta. Balai Penelitian dan Pengembangan agama. Jakarta.

18. Piliang, Yasraf A. 2006. Transpolitika: Dinamika Politik di Dalam Era Virtualitas. Yogyakarta: Jalasutra.

19. Rahardjo Turnomo. 2005. Menghargai Perbedaan Kultural: Mindfulness Dalam Komunikasi Antar Etnis. Yogyakarta: Pustaka Pelajar.

20. Ricoeur Paul. 2012. Teori Interpretasi Memahami Teks, Penafsiran, dan Metodologinya.Yogjakarta. IRCiSoD.

21. Riwut, Nila, 2003. Manaser Tatu Hiang, Menyelami Kekayaan Leluhur. Pustaka Lima. Palangka Raya.

22. Sanderson, Stephen K. 1993. Sosiologi Makro. Jakarta: Rajawali Press.

23. Suardika, I M. Pasek, I G. A. A. Ambarawati, I P. Sukaatmadja. 2006. "Analisis Perilaku Konsumen Terhadap Keputusan Pembelian Sayur Organik CV Golden Leaf Farm Bali". Jurnal Manajemen Agribisnis, Volume 2 No. 1.

24. Sumantri, 2001. "Ideologi dalam Pariwara" dalam Ida Sundari Husen dan Rahayu Hidayat. Merentas Ranah, Bahasa, Semiotika dan Budaya. Yogyakarta: Bentang.

25. Supriyono.2005. Teknologi Informasi dan Komunikasi.Jakarta: Yudhistira.

26. Takwin, Bagus. 2003. Akar-akar Ideologi, Pengantar Kajian Konsep Ideologi dari Plato Hingga Bourdieu. Yogyakarta \& Bandung: Jalasutra.

27. Penyusun, 2000. Upacara Ritual Keselamatan Hindu Kaharingan. Majelis Besar Agama Hindu Kaharingan Pusat Palangka Raya Provinsi Kaimantan Tengah.

28. Tim Penyusun, 2005. Panaturan. Kanwil Depag Provinsi Kalimantan Tengah.

29. Tim Penyusun. 2007. Upacara Tradisional Daerah Kalimantan Tengah, Dinas Pendidikan dan Kebudayaan. 